\title{
Kanaloplasti pada Atresia Liang Telinga Pasca Trauma
}

\author{
Jacky Munilson, Yan Edward, Surya Azani
}

\begin{abstract}
Abstrak
Pendahuluan: Atresia liang telinga didapat adalah suatu kelainan yang jarang terjadi dengan karakteristik pembentukan jaringan fibrosis pada liang telinga. Trauma pada liang telinga pada cedera kepala dapat menyebabkan atresia liang telinga pasca trauma dan menyebabkan tuli konduktif serta terbentuknya kolesteatom di daerah cul de sac sehingga diperlukan tatalaksana dengan pembedahan. Ada beberapa pendekatan teknik pembedahan kanoplasti yaitu dengan pendekatan transkanal, endaural dan postaurikula. Metode: Satu kasus atresia liang telinga didapat pasca trauma yang ditatalaksana dengan kanaloplasti transkanal dan bagian tulang yang terpapar ditutupi dengan flap kulit liang telinga. Hasil : Penyembuhan pasca operasi sangat memuaskan, liang telinga lapang dengan perbaikan fungsi pendengaran. Diskusi : Atresia liang telinga didapat salah satunya dapat disebakan oleh trauma dan dapat menimbulkan penurunan pendengaran. Pembedahan pada atresia liang telinga membutuhkan teknik yang khusus karena rekurensi dapat terjadi. Pembedahan dengan pendekatan transkanal sudah dapat memberikan akses yang adekuat. Bagian tulang liang telinga yang terpapar dapat ditutupi dengan flap ataupun graft kulit dengan vaskularisasi yang adekuat serta diperlukannya pembersihan liang telinga pasca operasi secara cermat dan teratur untuk mencegah rekurensi.
\end{abstract}

Kata kunci: Atresia liang telinga, trauma telinga, kanaloplasti transkanal.

\begin{abstract}
Introduction : Acquired ear canal atresia is a rare condition that characteristic by fibrotic tissue formation in ear canal. Trauma to the ear canal in head injury can cause post traumatic ear canal atresia with conductive hearing loss and cholesteatom in cul de sac area, so this condition necessary surgery procedure. There are several approaches of canaloplasty that are transcanal, endaural and postauricula approach canaloplasty. Methode : One case of post traumatic ear canal atresia that treated with transcanal approach canaloplasty and ear canal skin flap for closing the exposed bone. Result : satisfactory postoperative ear canal healing, with improvement of hearing function. Discussion: Acquired ear canal can be caused by trauma and can cause hearing loss. Surgery on the ear canal atresia requires special techniques because recurrence may occur. Transkanal surgical approach has been able to provide adequate access. The expose bone of ear canal after fibrotic tissue was removed, can be covered by skin flap or skin graft with adequate vascularity as well as the need for postoperative cleaning of the ear canal thoroughly and regularly to prevent recurrence.
\end{abstract}

Keywords: Ear canal atresia, ear trauma, transcanal canaloplasty.

Affiliasi penulis : Bagian Telinga Hidung Tenggorok Bedah Kepala Leher (THT-KL) Fakultas Kedokteran Universitas Andalas Padang. Korespondensi : Jacky Munilson, Bagian Telinga Hidung Tenggorok Bedah Kepala Leher (THT-KL) Fakultas Kedokteran Universitas Andalas Padang, email: jackymunilson@yahoo.co.id, Telp: 0751810900

\section{PENDAHULUAN}

Atresia liang telinga didapat merupakan kasus yang jarang dan beberapa istilah yang sering digunakan adalah fibrosis meatus media post inflamasi, fibrosis kanal medial post imflamasi, atresia didapat post infalamasi, atresia meatus akustikus eksterna dan stenosis liang telinga. Sekarang, istilah yang sering digunakan untuk atresia yang didapat sekunder terhadap proliferasi jaringan fibrosis di bagian medial liang telinga dari berbagai penyebab termasuk dalam kategori fibrosis meatus media. ${ }^{1.2}$

Istilah stenosis liang telinga sering digunakan untuk kasus atresia liang telinga, namun atresia liang telinga dan stenosis liang telinga sesungguhnya merupakan 2 hal yang berbeda. Atresia liang telinga didapat merupakan sumbatan atau plug jaringan lunak pada bagian medial liang telinga luar yang menempel pada bagian lateral membran timpani. Atresia liang telinga ini dapat disebabkan oleh trauma, pasca operasi, neoplasma atau pasca inflamasi. Stenosis liang telinga adalah penyempitan sepanjang liang telinga luar dimana terjadi penebalan jaringan subkutan. Stenosis liang telinga luar ini dapat disebabkan oleh malformasi kongenital atau didapat karena otitis eksterna persisten, trauma, keganasan atau irradiasi. ${ }^{1}$

Patofisiologi atresia liang telinga karena jaringan lunak belum jelas. Liang telinga diperkirakan mengalami beberapa tahap. Tahap pertama, beberapa kondisi seperti infeksi atau trauma menyebabakan tumbuhnya jaringan granulasi pada liang telinga, membran timpani atau pada keduanya. Jaringan granulasi terinfeksi dan terjadi proliferasi jaringan, tahap ini disebut tahap aktif atau fase immatur. Tahap 
matur terjadi ketika jaringan granulasi terus tumbuh dan dilapisi oleh epitel skuamosa. Proses ini berhenti pada bagian tulang liang telinga. ${ }^{3.4}$

Diagnosis atresia liang telinga dari pemeriksaan otoskopi, audiometri nada murni dan pemeriksaan penunjang tomografi komputer. Pada audiometri nada murni biasanya didapatkan tuli konduksi derajat sedang. Tomografi komputer resolusi tinggi tidak hanya memastikan adanya jaringan lunak di liang telinga, tapi juga menilai telinga tengah dan tulang pendengaran. ${ }^{2}$

Tatalaksana terbatas pada debridement lokal, antibiotik dan kauterisasi pada fase aktif atau fase infeksi. Ketika terjadi fibrosis atau fase matur pilihannya adalah pembedahan. ${ }^{3.4}$ Pembedahan dapat dilakukan melalui beberapa pendekatan yaitu pendekatan transkanal, pendekatan endaural dan pendekatan postaurikula. $^{3}$

\section{LAPORAN KASUS}

Seorang pasien laki-laki umur 16 tahun (MR 752029) datang ke poliklinik THT-KL RS. Dr. M. Djamil Padang pada tanggal 28 Desember 2011, dengan keluhan utama telinga kanan terasa tersumbat sejak 4 bulan yang lalu. Riwayat trauma kepala 4 bulan yang lalu, dengan perdarahan dari telinga kanan dan dirawat di bagian bedah RS. M. Djamil Padang. Penurunan pendengaran pada telinga kanan sejak 4 bulan yang lalu. Riwayat telinga kanan berair tidak ada.

Pemeriksaan fisik ditemukan keadaan umum tampak baik, kesadaran komposmentis kooperatif dan suhu badan tidak panas. Pada pemeriksaan fisik THT$\mathrm{KL}$ didapatkan telinga kanan, liang telinga buntu/ atresia. (Gambar 1A) Telinga kiri, liang telinga lapang, membran timpani utuh, reflek cahaya ada dan tidak ditemukan sekret. Hidung dan tenggorok dalam batas normal. Pemeriksaan pendengaran dengan tes garputala ditemukan Rinne: negatif pada telinga kanan, positif pada telinga kiri, Weber: lateralisasi ke kanan dan pemeriksaan Schwabach: memanjang pada telinga kanan dan pada telinga kiri sama dengan pemeriksa, didapatkan kesan tuli konduktif telinga kanan. Pada pemeriksaan audiometri didapatkan telinga kanan: Tuli konduktif sedang dengan ambang dengar $48.75 \mathrm{~dB}$, telinga kiri: normal dengan ambang dengar16.25 dB (Gambar 1B).

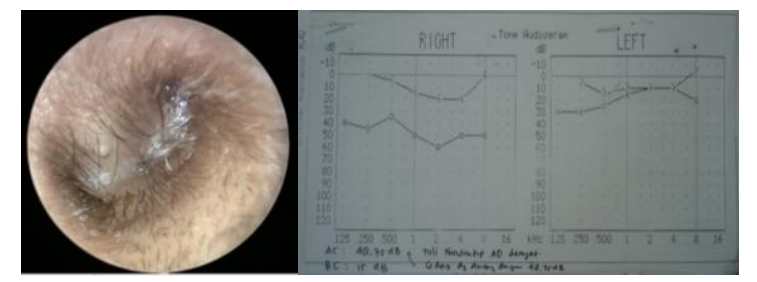

(A)

(B)

Gambar 1. A. Atresia liang telinga kanan pasca trauma. B. Grafik audiogram sebelum operasi dengan AB Gap 33.75 dB pada telinga kanan.
Berdasarkan hasil anamnesis dan pemeriksaan fisik ditegakkan diagnosis atresia liang telinga kanan pasca trauma. Pasien direncanakan untuk dilakukan operasi kanaloplasti liang telinga kanan dalam narkose umum. Dilakukan pemeriksaan tomografi komputer mastoid, pemeriksaan laboratorium darah untuk persiapan operasi.

Pada tomografi komputer tampak gambaran jaringan granulasi (soft tissue mass) yang menutupi meatus akustikus eksternus. Pneumatisasi air cell mastoid kanan dan kiri baik, tidak tampak perselubungan. Tampak tulang-tulang pendengaran masih intak. Tidak tampak gambaran destruksi. Tidak tampak gambaran abses di CPA. Kesan: suspek jaringan granulasi pada meatus akustikus eksternus dekstra. (Gambar 2). Pemeriksaan laboratorium darah didapatkan $\mathrm{Hb} 14.4 \mathrm{gr} \%$, leukosit $5.600 / \mathrm{mm}^{3}$, hematokrit 43\%, trombosit $326.000 \mathrm{u} / \mathrm{L}$, PT $13.4 \%$ dan APTT $39.5 \%$.

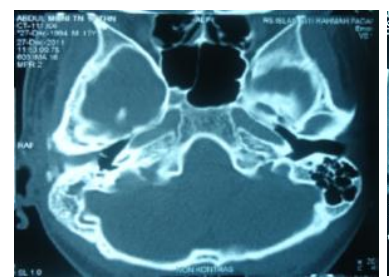

(A)

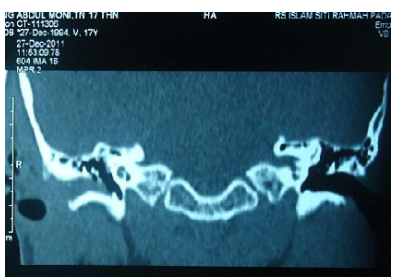

(B)
Gambar 2. Tomografi komputer mastoid. A. Potongan aksial, tampak gambaran soft tissue mass pada liang telinga kanan. B. Potongan koronal, tampak gambaran soft tissue mass pada liang telinga kanan dengan tulang pendengaran yang masih intak.

Pada tanggal 03 Januari 2012 dilakukan operasi kanaloplasti liang telinga kanan. Pasien tidur telentang di meja operasi dalam narkose umum dengan kepala miring ke kiri. Aseptik dan antiseptik di lapangan operasi dan dipasang duk steril. Evaluasi liang telinga kanan, tampak liang telinga mengalami atresia. Dilakukan infiltrasi dengan adrenalin 1:200.000 di liang telinga pada posisi jam jam 12, jam 3, jam 6 dan jam 9. Spekulum digunakan untuk melebarkan meatus selama pembedahan. Insisi horizontal dilakukan hingga batas kulit liang telinga yang mengalami atresia. Dilakukan pemisahan jaringan sikatrik secara tumpul mengelilingi kulit liang telinga dan dilakukan reseksi jaringan sikatrik. Reseksi jaringan sikatrik dan kulit liang telinga yang terlibat dimulai pada bagian inferior. Setelah jaringan sikatrik dan kulit yang terlibat diangkat, ditemukan debris antara jaringan sikatrik dan membran timpani, kemudian dibersihkan dan tidak tampak desruksi pada tulang. Membran timpani tampak utuh. Tampak penonjolan tulang dinding posterior liang telinga sepertiga tengah, dan dilakukan pengeboran. Dilakukan undermining pada kulit liang telinga yang tersisa dan dijadikan flap untuk menutupi tulang liang telinga yang terpapar. Tampon sofratul dipasang di liang telinga kanan dan telinga kanan ditutup verban. 
Pasien dirawat di bangsal THT-KL dengan diangnosis pasca kanaloplasti liang telinga kanan atas indikasi atresia liang kanan pasca trauma. Pasien diterapi dengan seftriakson $2 \times 1$ gram (iv) dan tramadol drip 1 ampul/500cc RL pada hari I, kemudian dilanjutkan dengan asam mefenamat $3 \times 500 \mathrm{mg}$ (PO).

Pada hari ke-3 pasca operasi verban diganti, liang telinga kanan tertutup tampon sofratul. Pada hari ke-7 pasca operasi tampon sofratul pada liang telinga diangkat, tampak liang telinga lapang, tulang dinding posterior liang telinga sepertiga luar masih terpapar dan tampon sofratul kembali dipasang. Pada hari ke-9 pasca operasi, tampon sofratul pada liang telinga kanan diangkat lagi, tampak tulang dinding posterior liang telinga sepertiga luar masih terpapar dengan ukuran yang makin kecil. Tampon sofratul dipasang lagi. Pada hari ke-11 pasca operasi, tampon sofratul kembali diangkat, tampak liang telinga kanan lapang, tulang dinding posterior liang telinga yang terpapar sudah mengecil dan tampon sofratul kembali dipasang. Pada hari ke-13 pasca operasi, tampon sofratul kembali diangkat, tampak liang telinga kanan lapang, tulang dinding posterior liang telinga yang terpapar sudah mulai mengecil. Tampon sofratul kembali dipasang untuk mencegah sikatrik pasca operasi. Pasien dipulangkan dengan terapi cefixime 2x100 mg (PO) dan dianjurkan kontrol ke poliklinik 3 hari sekli untuk ganti tampon sofratul.

Pemasangan tampon sofratul setiap 3 hari sekali dilakukan selama follow up sampai luka pada liang telinga menutup sempurna sampai hari ke-22 pasca operasi. (gambar $3 \mathrm{~A}$ ). Follow up 1.5 bulan pasca operasi, liang telinga tampak lapang, membran timpani utuh dan reflek cahaya ada. ( gambar 3B)

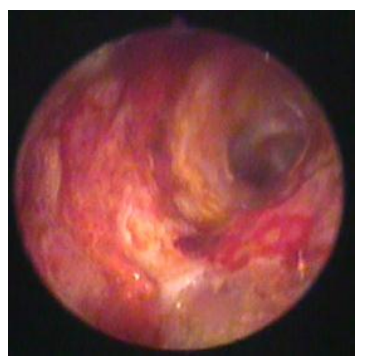

(A)

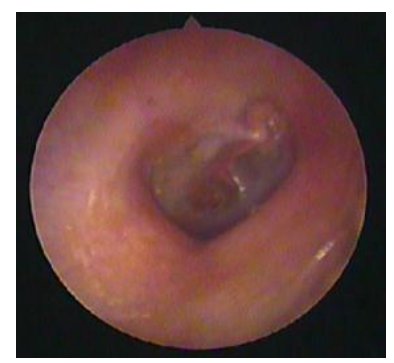

(B)
Gambar 3. Liang telinga kanan A. 22 hari pasca operasi, luka operasi masih hiperemis. B. 1.5 bulan pasca operasi, lapang dan luka operasi sudah tenang

Pemeriksaan pendengaran diulang 1 bulan pasca operasi didapatkan telinga kanan: normal dengan ambang dengar $12.5 \mathrm{~dB}$. AS: normal dengan ambang dengar $10 \mathrm{~dB}$. (gambar 4)

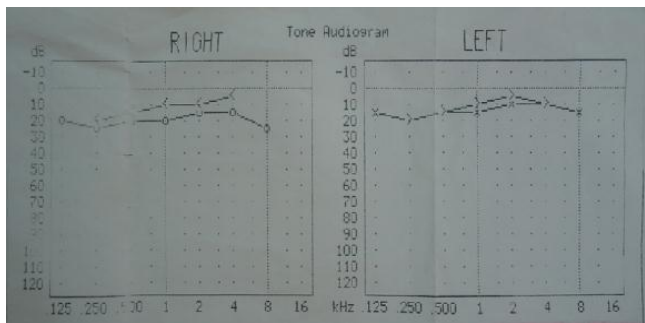

Gambar 4. Audiogram pasca operasi dengan AB Gap $7.5 \mathrm{~dB}$ pada telinga kanan.

\section{DISKUSI}

Telah dilaporkan satu kasus laki-laki 16 tahun dengan diagnosis atresia liang telinga kanan pasca trauma. Keluhan yang dialami pasien adalah telinga kanan tersumbat disertai penurunan pendengaran sejak mengalami cedera kepala 4 bulan yang lalu.

Atresia liang telinga didapat sering ditemukan dibagian medial sehingga dikenal juga dengan istilah fibrosis liang telinga medial yang merupakan suatu bentukan sikatriks dari jaringan fibrosis. ${ }^{5}$ Atresia liang telinga didapat ini biasanya disebabkan karena infeksi dan peradangan kronik liang telinga, tindakan pembedahan sebelumnya atau trauma. ${ }^{4-6}$

Becker dan Tos, seperti yang dikutip oleh Harcourt $^{7}$ menemukan Insiden atresia liang telinga yang didapat 0.5 per 100.000 pasien yang datang ke klinik otologi di Copenhagen, dimana atresia tipe membran 20 kali lebih kecil dibanding tipe solid. Klinik otology yang besar di Tubingen, Jerman melaporkan 6 kasus atresia liang telinga tipe solid yang menjalani operasi dan klinik THT yang cukup besar di London melaporkan hanya 7 kasus atresia fibrosa didapat yang menjalani operasi dalam 10 tahun. $^{8}$ Di RS. M. Djamil Padang, belum ada data tentang atresia liang telinga yang didapat akibat trauma kecelakaan lalu lintas dan menjalani pembedahan kanaloplasti.

Tos \& Bonding seperti yang dikutip oleh Harcourt $^{7}$, Becker ${ }^{8}$ Luong $^{9}$, membagi atresia liang telinga luar dalam dua kategori yaitu tipe solid dan tipe membran. Atresia liang telinga tipe solid yaitu liang telinga yang buntu karena terbentuknya jaringan ikat pada bagian medial liang telinga, yang berhubungan dengan membran timpani. (Gambar 5A). Tipe solid biasanya berhubungan dengan otitis eksterna atau otitis media. Atresia liang telinga tipe membran yaitu terbentuknya suatu membran yang terdiri dari jaringan ikat yang dilapisi oleh epitel kulit liang telinga pada bagian medial dan lateral membran, terbentuknya membran jauh dari membran timpani sehingga membagi liang telinga menjadi bagian lateral dan medial, pada bagian medial dapat ditemukan 
kolesteatom (Gambar 5B). Tipe membran ini terutama disebabkan oleh trauma, di presipitasi oleh iritasi sirkular, luka bakar atau ulserasi kulit liang telinga yang melingkar. Beberapa etiologi dapat menyebakan atresia liang telinga sepert yang telah diuraikan di atas, tetapi patogenesisnya secara umum adalah adanya respon imflamsi fibroprolifertif. ${ }^{9}$

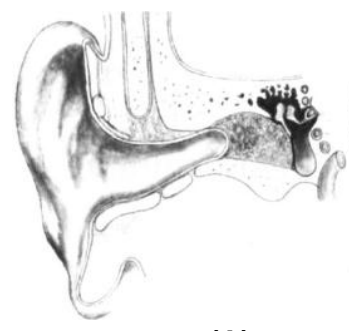

(A)

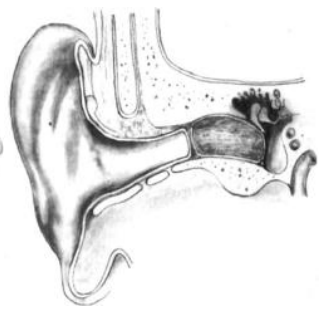

(B)
Gambar 5. Atresia liang telinga. A tipe solid B. tipe membran $^{8}$

Pada pasien ini ditemukan jaringan fibrosis di liang telinga kanan, dimana pada bagian lateralnya dilapisi kulit liang telinga dan pada bagian medial sulit untuk di identifikasi apakah juga dilapisi oleh kulit liang telinga. Jenis atresia pada pasien ini menyerupai atresia tipe membran, walaupun bagian medial jaringan fibrotik sulit diidentifikasi lapisan kulitnya. Antara jaringan fibrosis dan membran timpani yang utuh ditemukan debris tetapi tidak ditemukan tandatanda destruksi tulang liang telinga.

Tomografi komputer pada kasus atresia liang telinga pasca trauma untuk mengevaluasi telinga tengah, mastoid dan kondisi tulang pendengaran serta kemungkinan adanya kolesteatom. Adanya kolesteatom yang meluas dari liang telinga ke telinga tengah dan kavum mastoid akan mempengaruhi teknik pembedahan. ${ }^{9}$ Tatalaksana atresia liang telinga didapat, dapat dengan medikamentosa pada fase infeksi atau dengan pembedahan jika sudah terjadi fibrosis. Terapi pembedahan diindikasikan untuk koreksi tuli konduksi dan untuk mencegah terbentunya kolesteatom. $^{6}$

Pembedahan dapat dilakukan dengan pendekatan transkanal, endaural atau pendekatan postaurikula. ${ }^{3.6}$ Pada kebanyakan kasus, akses yang adekuat sudah dapat dicapai dengan pendekatan transkanal dengan menggunakan spekulum. ${ }^{7}$ Bagian kulit yang terlibat diangkat, bagian tulang dilebarkan dengan bor untuk mencegah atresia berulang, jika trauma pada membran timpani tidak dapat dihindari, dapat dilakukan timpanoplasti. Bagian tulang yang terpapar ditutup dengan epitel, dapat dengan menggunakan flap pedikel atau full-thickness skin graft. Jika tulang dibiarkan terpapar, jaringan granulasi mudah tumbuh dan dapat terjadi atresia lagi. Kassa steril dimasukkan ke liang telinga dan dipertahankan selama 10-14 hari. $^{6}$

Pada pasien ini dilakukan teknik kanaloplasti transkanal dan bagian tulang yang terpapar ditutup dengan flap kulit liang telinga yang tersisa. Flap kulit yang digunakan ternyata tidak cukup untuk menutupi bagian tulang yang terpapar dimana terlihat pada saat tampon sofratul dibuka hari ke-7, masih ada bagian tulang yang terpapar dibagian posterior. Becker ${ }^{8} \mathrm{dkk}$ juga menggunakan insisi transkanal pada pada 53 pasien atresia liang telinga yang didapat dan bagian tulang yang terpapar ditutup dengan split-thicness skin graft. Teknik operasi seperti telihat pada gambar 6 .

$\mathrm{Lin}^{4}$ dkk dalam penelitiannya menggunakan teknik insisi endaural, jaringan fibrosis dilepaskan sampai permukaan epitel membran timpani, kemudian liang telinga dan membran timpani ditutupi dengan split-thickness skin graft, liang telinga diisi dengan kapas yang mengandung antibiotik. Kapas ini diangkat pada hari ke-14. Sepuluh telinga (38.5\%) dari 26 telinga sembuh tanpa komplikasi, sisanya dengan komplikasi dan rekurensi. Perbaikan pendengaran 18 $(69.2 \%)$ dari 26 pembedahan
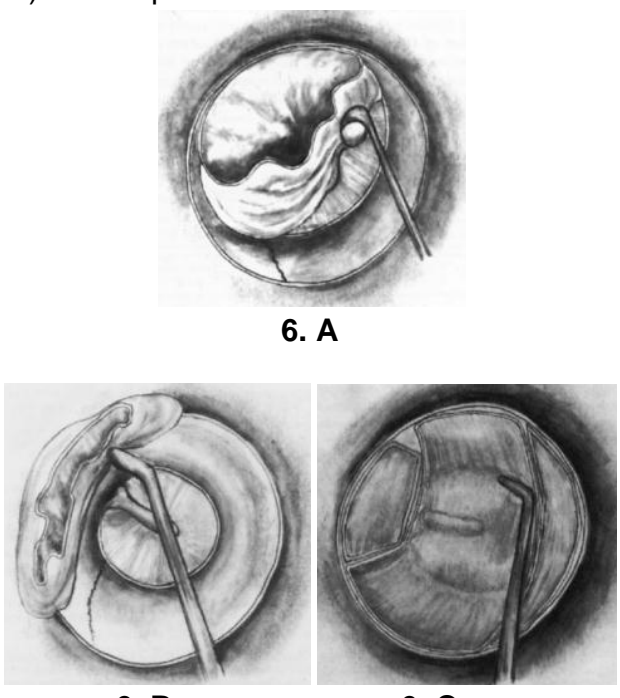

6. B

6. C

Gambar 6. A; insisi sirkumferensial, lateral dari jaringan fibrosis. B; pengangkatan jaringan fibrosis sampai ke annulus fibrosus dan lamina propria MT. C; graft menutupi bagian tulang yang terpapar dan $\mathrm{MT}^{8}$

Jacobsen $^{1}$ dkk menggunakan teknik insisi post aurikula pada 16 pasien dan 14 dengan menggunakan split skin graft, 57\% liang telinga paten dan $29 \%$ rekurensi terjadi dalam waktu 1-2 tahun. Perbaikan pendengaran terjadi pada 11 pasien (79\%) dimana $64 \%$ AB gap $<20$ dB. Rendahya perbaikan ini mungkin disebabkan adanya penyakit dasar di telinga tengah atau terjadinya sklerosis membran timpani pasca operasi

Banyak teknik yang digunakan untuk menutupi tulang liang telinga yaitu flap meatal, flap regional/ flap pedikel sekitar liang telinga, FullThickness Skin Grafts (FTSGs) dan Split-Thickness Skin Grafts (STSGs). ${ }^{9}$ Penggunaan flap kulit sekitar telinga dengan vaskularisasi yang lebih baik pada literatur dianjurkan pada atresia liang telinga kongenital maupun didapat. Bell seperti yang dikutip oleh Dhooge dan Vermeersch ${ }^{10}$ menggunakan flap kulit kranial anterior dan flap kulit distal posterior. Hal yang sama dilakukan oleh Dhooge dan Vermeersch 
pada empat orang pasien dengan atresia liang telinga. Pasca operasi didapatkan liang telinga yang kering dalam beberapa minggu dengan scar yang hampir tidak telihat. Adkins dan Osguthphore, seperti yang dikutip oleh Luong, ${ }^{9}$ menggunakan flap preaurikula superior. Kerugian menggunakan flap sekitar liang telinga ini adalah kulit liang telinga bagian medial akan mengandung kelenjar apokrin dan kelenjar sebasea yang tidak ditemukan dalam keadaan normal. Graft kulit yang digunakan untuk menutupi bagian tulang liang telinga yang terpapar dapat berupa FTSGs atau STSGs. Moore dkk, seperti yang dikutip oleh Luong ${ }^{9}$ menggunakan FTSGs. Kekurangan dalam penggunaan graft kulit ini adalah, liang telinga bagian tulang merupakan tulang kortikal padat yang kurang ideal untuk pertumbuhan graft sehingga graft dapat tidak tumbuh dengan sempurna, setelah fase penyembuhan akan terbentuk lapisan kulit yang tipis yang tidak tahan terhadap air. ${ }^{10}$

Kolesteatom dapat terbentuk pada derah cul de sac atresia liang telinga. McKennan ${ }^{11}$ menemukan kolesteatom pada 2 kasus atresia liang telinga pasca trauma. Hal ini penting untuk diketahui oleh ahli bedah lain untuk menkosultasikan pasien dengan keterlibatan cedera pada liang jika keadaan pasien sudah stabil. Pada Hal yang sama juga ditemukan pada kasus ini dimana kolesteatom ditemukan antara jaringan fibrosis dan membran timpani yang masih utuh.

Pemeriksaan audiometri pasca operasi didapatkan perbaikan pendengaran pasca operasi dengan AB Gap 33,75 dB menjadi 7.5 dB. Suzuikawa dkk juga melakukan teknik yang sama pada 4 orang pasiennya dan menunjukkan hasil pasca operasi yang bagus dimana terlihat perbaikan pendengaran pada semua pasien

Pembedahan pada atresia liang telinga membutuhkan teknik yang khusus karena rekurensi dapat terjadi. Rekurensi atresia liang telinga ini juga tergantung kepada penyakit dasarnya dengan angka kegagalan dapat mencapai $10-20 \% .^{2.4}$ Becker $^{8}$ dkk mendapatkan angka rekurensi $11 \%$ pasca operasi dari 53 kasus atresia liang telinga yang dioperasi dengan teknik transkanal. Rekurensi ini mungkin terjadi karena pengangkatan jaringan ikat yang tidak komplit dan sebagian terbentuk karena otitis eksterna. $\mathrm{Lin}^{4} \mathrm{dkk}$ mengusulkan klasifikasi untuk menilai tingkat keberhasilan operasi seperti yang telihat pada tabel 1 . Tujuan klasifikasi ini adalah untuk membandingkan hasil pembedahan dengan peneliti lain. $\operatorname{Lin}^{4} \mathrm{dkk}$ membedakan hasil pembedahan dengan self-cleaning yang normal (derajat I) dengan yang tidak normal (derajat II \& III). Berdasarkan klasifikasi ini, maka tingkat keberhasilan operasi pada kasus ini termasuk kepada kelompok derajat 1.
Tabel 1. Klasifikasi yang diajukan Lin dkk untuk menilai tingkat keberhasilan operasi ${ }^{4}$

\begin{tabular}{cl}
\hline Derajat & \\
\hline I & $\begin{array}{l}\text { Normal, Membran timpani dan self- } \\
\text { cleaning liang telinga }\end{array}$ \\
\hline II & $\begin{array}{l}\text { Membran timpani tipis, tebal atau } \\
\text { perforasi ; dengan atau tanpa miringitis } \\
\text { ringan ; tidak ada self-cleaning liang } \\
\text { telinga dengan penumpukan keratin ; tidak } \\
\text { ada polyps }\end{array}$ \\
\hline III & Rekuren, dengan atau tanpa infeksi. \\
\hline
\end{tabular}

Banyak metode telah dikembangkan untuk mempertahankan patensi liang telinga pasca pembedahan dan ada beberapa prinsip pembedahan tertentu yang dapat memprediksi hasil operasi yang baik, yaitu: kanaloplasti yang lebar, yakinkan permukaan tulang sudah halus, graft yang multipel lebih baik daripada graft tunggal, penggunaan gelfilm dan tampon yang baik pada liang telinga dan pembersihan liang telinga pasca operasi secara cermat dan teratur. ${ }^{2.4}$

\section{DAFTAR PUSTAKA}

1. Jacobsen N, Mills R. Management of stenosis and acquired atresia of the external auditory meatus. Laringology \& Otology. 2006: 120; 266-71.

2. Suzukawa K, Karino S, Yamasoba T. Surgical treatment of medial meatal fibrosis Report of four cases. Auris Nasus Larynx. 2007: 34; 365-8.

3. Buton LK, Driscoll CLW. Canaloplasty Atresia. In Haberman RS. Middle ear and mastoid surgery. Thieme. New York. 2004 ; p. 177-87

4. Lin VY, Chee GH, David EA, Chen JM.Medial Canal Fibrosis : Surgical technique, result and propose grading system. Otology \& Neurootology. 2005: 26; 825-29.

5. El-Sayed Y. Acquired medial canal fibrosis. The journal of Laryngologu and Otology. 1998; 112: $145-9$

6. Kroon DF, Strasnick B. Diseases of the Auricle, External Auditory Canal, and Tympanic Membrane. In GalsscockSambought. Surgery of the ear. $5^{\text {th }}$ Ed. BC Decker Inc. Hamilton Ontario. 2003: p. 345-67

7. Harcourt JP. Acquired atresia of the external ear. In Gleesom M et al eds. Scott-Brown' Otorhinolaryngology Head and Neck Surgery, $7^{\text {nd }}$ ed. 2008. p. 3346-50.

8. Becker B, Tos M. Postinflammatory Acquired Atresia of the External Auditory Canal: Treatment and Results of Surgery Over 27 Years. Laryngoscope. 1998: 108; 903-7.

9. Luong A, Roland PS. Acquired external 
auditory canal stenosis: assessment and management. Cur Opin, Otolaryngol Head and Neck Surg. Lippincott Williams \& Wilkins. 2005: 13; 273-6.

10. Dhooge IJM, Vermeersch HFE. The use of two pedicle flaps in the surgical treatment of acquired atresia of the outer ear canal. Clin. Otolaryngology. 199: 24; 58-60.

11. McKennan K, Chole R. Traumatic external auditory canal atresia. The American Journal of otology.1992: 13; 80-1. 